\title{
Thermodynamics and high-pressure kinetics of a fast carbon dioxide fixation reaction by a (2,6-pyridinedicarboxamidato-hydroxo)nickel(II) complex $\dagger$
}

Cite this: Dalton Trans., 2014, 43, 5274

Received 24th October 2013, Accepted 29th January 2014

DOI: $10.1039 / c 3 d t 53004 c$

www.rsc.org/dalton

\author{
O. Troeppner, ${ }^{a}$ D. Huang, ${ }^{\text {b }}$ R. H. Holm ${ }^{\text {b }}$ and I. Ivanović-Burmazović ${ }^{\star a}$
}

The previously reported carbon dioxide fixation reaction by the planar terminal hydroxide complex $\left[\mathrm{Ni}\left(\mathrm{pyN}_{2}{ }^{\mathrm{Me} 2}\right)(\mathrm{OH})\right]^{1-}$ in DMF has been further characterized by determination of the equilibrium constants $K_{\mathrm{eq}}^{298}=2.4 \pm 0.2 \times 10^{5} \mathrm{M}^{-1}$ and $K_{\mathrm{eq}}^{223}=1.3 \pm 0.1 \times 10^{7} \mathrm{M}^{-1}$, as well as the volume of activation for the $\mathrm{CO}_{2}$ binding $\left(\Delta V_{\mathrm{on}}^{\neq 223}=\right.$ $\left.-21 \pm 3 \mathrm{~cm}^{3} \mathrm{~mol}^{-1}\right)$ and back decarboxylation $\left(\Delta V_{\mathrm{off}}^{\neq 223}=\right.$ $-13 \pm 1 \mathrm{~cm}^{3} \mathrm{~mol}^{-1}$ ) by high-pressure kinetics. The data are consistent with an earlier DFT computation, including the probable nature of the transition state, and support designating the reaction as one of the most completely investigated carbon dioxide fixation reactions of any type.

Fixation and utilization of $\mathrm{CO}_{2}$ is an increasingly prominent problem ${ }^{1-4}$ not only because $\mathrm{CO}_{2}$ is a contributor to the greenhouse effect, but also because of its importance as a potentially cheap, nontoxic and abundant source of renewable synthetic fuels. ${ }^{5}$ There are many general approaches that can lead to fixation and utilization of $\mathrm{CO}_{2}$ to form energetically more valuable molecules like carbon monoxide, methanol or methane, ranging from photochemical ${ }^{6-18}$ to electrochemical $^{1,5,19-34}$ to chemical reduction ${ }^{35-43}$ pathways. They often involve a variety of transition metal centers as redox catalysts, ranging from rather expensive and rare metals like ruthenium $^{21}$ and platinum ${ }^{44}$ to cheaper and more abundant ones like nickel ${ }^{2,45}$ and copper. ${ }^{1}$ A number of metal complexes have been synthesized and investigated as possible mimics of naturally occurring carbon monoxide dehydrogenase $(\mathrm{CODH})$, an enzyme catalyzing the reversible redox reaction $\mathrm{CO}_{2}+2 \mathrm{H}^{+}+2 \mathrm{e}^{-} \rightleftharpoons \mathrm{CO}+\mathrm{H}_{2} \mathrm{O}$ and either containing $\mathrm{Mo}-\mathrm{Cu}-\mathrm{S}$ or $\mathrm{Ni}-\mathrm{Fe}-\mathrm{S}$ active sites. ${ }^{46-49}$

\footnotetext{
${ }^{a}$ Department of Chemistry and Pharmacy, University of Erlangen-Nürnberg, Egerlandstr. 1, 91058 Erlangen, Germany. E-mail: ivana.ivanovic-burmazovic@fau.de

${ }^{b}$ Department of Chemistry and Chemical Biology, Harvard University, Cambridge, Massachusetts 02138, USA. E-mail: holm@chemistry.harvard.edu

$\dagger$ Electronic supplementary information (ESI) available: Rate constants for the $\mathrm{CO}_{2}$ uptake $\left(k_{\mathrm{on}}\right)$ and decarboxylation $\left(k_{\text {off }}\right)$ at elevated pressures. See DOI: $10.1039 / \mathrm{c} 3 \mathrm{dt} 53004 \mathrm{c}$
}

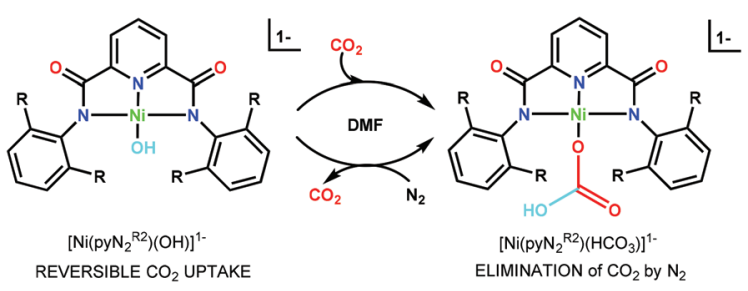

Scheme 1 Reversible carbon dioxide fixation reaction mediated by $\left[\mathrm{Ni}\left(\mathrm{pyN}_{2}{ }^{\mathrm{R} 2}\right)(\mathrm{OH})\right]^{1-}$.

Besides redox methods, carbon dioxide fixation can also be achieved through non-redox processes. ${ }^{4}$ Of the latter, reactions of a terminal $\mathrm{M}^{\mathrm{II} / \mathrm{III}}-\mathrm{OH}$ group with $\mathrm{CO}_{2}$ to afford bridging carbonate and terminal or bridging bicarbonate products are well documented. ${ }^{50-54}$ Nature utilizes such a reaction within the catalytic cycle of carbonic anhydrases, where the terminal hydroxo group at the four-coordinate $\mathrm{Zn}^{\mathrm{II}}$ center plays a crucial role in the reversible hydration of $\mathrm{CO}_{2} \cdot{ }^{55}$ Formation of a unidentate bicarbonate complex seems to be critical for the efficiency of that catalytic cycle. ${ }^{56}$ Some of us have recently observed that members of a set of planar terminal hydroxo complexes derived from $N, N^{\prime}$-2,6-disubstituted phenyl-2,6dicarboxamide pincer ligands react rapidly and completely with $\mathrm{CO}_{2}$ in DMF to form $\eta^{1}$-bicarbonate products (Scheme 1). ${ }^{3,57}$ Reactions are second-order with rate constants (ca. $10^{4}-10^{6} \mathrm{M}^{-1} \mathrm{~s}^{-1}$ ) that tend to decrease as the steric size of the phenyl R-substituents increases. The most notable feature is the second-order rate constant $k_{\text {on }}=9.5 \times 10^{5} \mathrm{M}^{-1} \mathrm{~s}^{-1}$ for reaction (1) at $298 \mathrm{~K}$ (Table 1 ), extrapolated from measurements at lower temperatures. ${ }^{3}\left[\mathrm{Ni}\left(\mathrm{pyN}^{\mathrm{Me} 2}\right)(\mathrm{OH})\right]^{1-}$ carries the smallest ortho-substituent in the set; the unsubstituted ligand forms octahedral $\left[\mathrm{Ni}\left(\mathrm{pyN}_{2}\right)_{2}\right]^{2-} \cdot{ }^{58}$

$$
\left[\mathrm{Ni}\left(\mathrm{pyN}_{2}^{\mathrm{Me} 2}\right)(\mathrm{OH})\right]^{1-}+\mathrm{CO}_{2} \underset{k_{\text {off }}}{\stackrel{k_{\text {on }}}{\rightleftharpoons}}\left[\mathrm{Ni}\left(\mathrm{pyN}_{2}^{\mathrm{Me} 2}\right)\left(\mathrm{OCO}_{2} \mathrm{H}\right)\right]^{1-}
$$

Comparison of $k_{\text {on }}^{298}$ for reaction (1) with second-order rate constants for other systems including model reactions for 
Table 1 Observed equilibrium and kinetic parameters for the reaction (1) of the $\mathrm{R}=\mathrm{CH}_{3}$ complex in DMF

\begin{tabular}{ll}
\hline$K_{\mathrm{eq}}^{298}$ & $2.4 \pm 0.2 \times 10^{5} \mathrm{M}^{-1 a}$ \\
$K_{\mathrm{eq}}^{223}$ & $1.3 \pm 0.1 \times 10^{7} \mathrm{M}^{-1 a}$ \\
$k_{\mathrm{on}}^{298}$ & $9.5 \times 10^{5} \mathrm{M}^{-1} \mathrm{~s}^{-1 b}$ \\
$\Delta H_{\mathrm{on}}^{\neq}$ & $3.2 \pm 0.5 \mathrm{kcal} \mathrm{mol}^{-1 b}$ \\
$\Delta S_{\mathrm{on}}^{\neq}$ & $-20 \pm 3 \mathrm{cal} \mathrm{mol}^{-1} \mathrm{~K}^{b}$ \\
$\Delta V_{\mathrm{on}}^{\neq 223}$ & $-21 \pm 3 \mathrm{~cm}^{3} \mathrm{~mol}^{-1 a}$ \\
$\Delta V_{\mathrm{off}}^{\neq 223}$ & $-13 \pm 1 \mathrm{~cm}^{3} \mathrm{~mol}^{-1 a}$ \\
${ }^{a}$ This work. ${ }^{b}$ Ref. 3. &
\end{tabular}

the $\mathrm{Zn}$ (II) enzyme carbonic anhydrase reveals an increase of $\geq 10^{3} \mathrm{M}^{-1} \mathrm{~s}^{-1}$. Further, under the approximation $k_{\text {on }} \approx k_{\text {cat }} / K_{\mathrm{M}}$ the rate constant overlaps the enzyme range of $c a \cdot 10^{5}-10^{8} \mathrm{M}^{-1}$ $\mathrm{s}^{-1} \cdot{ }^{55}$ While precise comparisons cannot be made between synthetic or enzyme systems and reaction (1) owing to solvent differences (aqueous vs. DMF), it is nonetheless evident that this reaction is an unusually rapid $\mathrm{CO}_{2}$ fixation process. Such a rapid $\mathrm{CO}_{2}$ fixation appears to be related to several notable features of $\left[\mathrm{Ni}\left(\mathrm{pyN}_{2}{ }^{\mathrm{Me} 2}\right)(\mathrm{X})\right]^{-}$: presence of the uncommon terminal $\mathrm{Ni}^{\mathrm{II}}-\mathrm{OH}$ group in the reactant and unidentate $\eta^{1}-\mathrm{OCO}_{2} \mathrm{H}$ bicarbonate in the product complex, despite the four-coordinate ligand environment around the $\mathrm{Ni}^{\mathrm{II}}$ center. ${ }^{3}$

Although the reversible character of this process has been qualitatively demonstrated, ${ }^{57}$ quantification of this equilibrium and the back decarboxylation reaction has not yet been reported. Since the efficiency of a $\mathrm{CO}_{2}$ uptake is related to a $\mathrm{CO}_{2}$ binding constant, the equilibrium constant $K_{\text {eq }}$ of reaction (1) was thermodynamically and kinetically determined in this study at $298 \mathrm{~K}$ and $223 \mathrm{~K}$, respectively, contributing to understanding of the overall solution thermodynamics. Moreover, there are no literature data for binding constants of $\mathrm{CO}_{2}$ to $\mathrm{Ni}-\mathrm{OH}$ species. The only binding constant reported is for a Zn-hydroxo complex at $217 \mathrm{~K} .{ }^{53}$ Kinetic characterization of the reaction so far has disclosed a low enthalpic barrier and a large negative entropy of activation consistent with a secondorder reaction (Table 1). However, to fully comprehend the nature of this rather unique low activation pathway for $\mathrm{CO}_{2}$ insertion, here we sought to determine the pressure effect on its kinetics, applying unique high-pressure cryo-temperature stopped-flow measurements at $223 \mathrm{~K}$ and $0.5-70 \mathrm{MPa}$. This is important not only with respect to the determination of the volume of activation $\left(\Delta V^{\neq}\right)$and thus visualization of a reaction transition state, but also considering an increase in solubility of $\mathrm{CO}_{2}$ under low temperature and high pressure conditions, which can have an impact on the efficiency of $\mathrm{CO}_{2}$ sequestering on a larger scale.

The compounds $\left(\mathrm{Et}_{4} \mathrm{~N}\right)\left[\mathrm{Ni}\left(\mathrm{pyN}_{2}{ }^{\mathrm{Me} 2}\right) \mathrm{X}\right]\left(\mathrm{X}=\mathrm{OH}^{-}, \mathrm{HCO}_{3}{ }^{-}\right)$ were prepared as described. ${ }^{46}+$ To elucidate the reversible nature of reaction (1) and to determine its equilibrium constant $K_{\text {eq }}$, a spectrophotometric titration was undertaken in which small aliquots of solutions of $\mathrm{CO}_{2}$ in DMF were added to a $0.1 \mathrm{mM}$ solution of $\left[\mathrm{Ni}\left(\mathrm{pyN}_{2}{ }^{\mathrm{Me} 2}\right)(\mathrm{OH})\right]^{1-}$ in DMF at $298 \mathrm{~K}$ in a $1 \mathrm{~cm}$ path-length septum-capped and gas-tight UV/visible cuvette. Saturated solutions of $\mathrm{CO}_{2}$ in DMF $(0.2 \mathrm{M})^{59,60}$ were
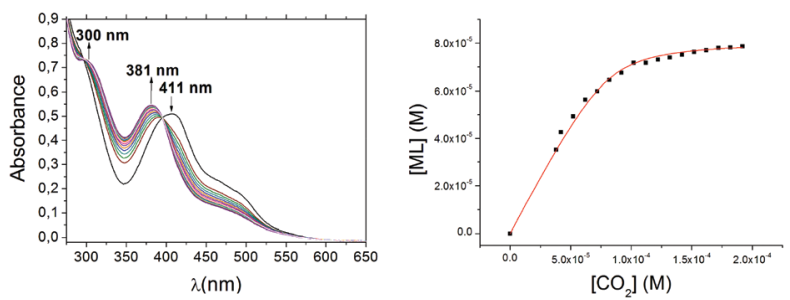

Fig. 1 UV/visible spectral changes upon addition of small aliquots of $\mathrm{CO}_{2}$ in DMF to a $0.1 \mathrm{mM}$ solution of $\left[\mathrm{Ni}\left(\mathrm{pyN}_{2}{ }^{\mathrm{Me} 2}\right)(\mathrm{OH})\right]^{1-}$ in DMF at room temperature (left). Plot of the concentration changes of the bicarbonate reaction product ([ML], based on the absorbance change at $381 \mathrm{~nm}$ ) as dependent on $\left[\mathrm{CO}_{2}\right]$; the red line is a fit to eqn (2) (right).

prepared by bubbling $\mathrm{CO}_{2}$ gas at room temperature through argon-saturated dry DMF in a $10 \mathrm{~mL}$ gas-tight Hamilton syringe. Because the concentration of $\mathrm{CO}_{2}$ required for the titration was not in a high excess over the complex concentration, spectrophotometric data were analyzed with eqn (2) in which $[\mathrm{ML}]$ is the concentration of the product as a function of the concentration of $\mathrm{CO}_{2}\left(\left[\mathrm{~L}_{0}\right]\right),\left[\mathrm{M}_{0}\right]$ is the total complex concentration and $K_{\text {eq }}$ is the equilibrium constant. The change in the overall volume of a reaction mixture in the course of a titration is negligible because of the small amount of $\mathrm{CO}_{2}$ titrant solution added. After the addition of $\mathrm{CO}_{2}$ and prior to an absorbance measurement, the reaction mixture was allowed to equilibrate for $20 \mathrm{~s}$.

$[\mathrm{ML}]=\frac{1+K_{\mathrm{eq}}\left(\left[\mathrm{M}_{0}\right]+\left[\mathrm{L}_{0}\right]\right)-\sqrt{\left(1+K_{\mathrm{eq}}\left(\left[\mathrm{M}_{0}\right]+\left[\mathrm{L}_{0}\right]\right)\right)^{2}-4 K_{\mathrm{eq}}{ }^{2}\left[\mathrm{M}_{0}\right]\left[\mathrm{L}_{0}\right]}}{2 K_{\mathrm{eq}}}$

The UV/visible spectra obtained in the course of the titration are depicted in Fig. 1(left). Observed absorbance changes and tight isosbestic points at 279 and $395 \mathrm{~nm}$ are consistent with previous results ${ }^{3}$ describing the expected single-step reaction; the concentration of the product $v s$. $\left[\mathrm{CO}_{2}\right]$ is shown in Fig. 1(right). Analysis of the global spectra data with eqn (2) leads to $K_{\mathrm{eq}}^{298}=2.4 \pm 0.2 \times 10^{5} \mathrm{M}^{-1}$.

Using $K_{\mathrm{eq}}=k_{\mathrm{on}} / k_{\mathrm{off}}$, we estimate the first order rate constant $k_{\text {off }}$ for the back decarboxylation reaction to be $4 \mathrm{~s}^{-1}$ at $298 \mathrm{~K}$. We have previously demonstrated the reversibility of the binding reaction by its reversal upon passing dinitrogen through a solution of $\left[\mathrm{Ni}\left(\mathrm{pyN}_{2}{ }^{\mathrm{Me} 2}\right)\left(\mathrm{OCO}_{2} \mathrm{H}\right)\right]^{1-3,57}$

The only other quantified equilibrium for $\mathrm{CO}_{2}$ fixation is bicarbonate formation by $\mathrm{CO}_{2}$ insertion in a $\mathrm{Zn}-\mathrm{OH}$ bond $\left(K_{\text {eq }}=6 \pm 2 \times 10^{3} \mathrm{M}^{-1}\right.$ in dichloromethane at $217 \mathrm{~K}$, corresponding to $\left.\Delta G=-3.8 \pm 0.2 \mathrm{kcal} \mathrm{mol}{ }^{-1}\right) .{ }^{53}$ Under comparable low temperature conditions in DMF, reaction (1) is three to five orders of magnitude more efficient with estimated binding constants in the $4 \times 10^{7}$ to $8 \times 10^{8} \mathrm{M}^{-1}$ range. The values were estimated from our $K_{\mathrm{eq}}$ value and reaction enthalpies previously computed with BP86 and B3LYP functionals, respectively. $^{3}$ 

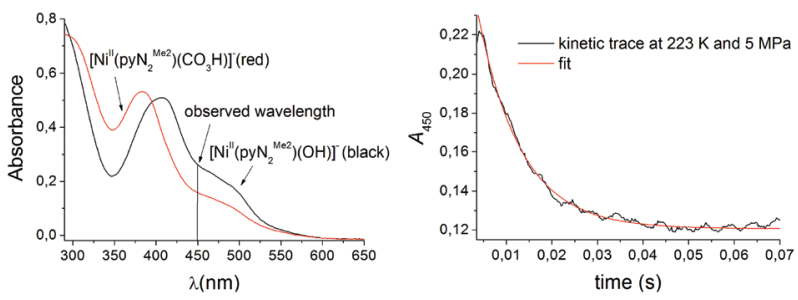

Fig. 2 Spectral changes upon the reaction of $1 \mathrm{mM} \mathrm{CO}_{2}$ and $0.1 \mathrm{mM}$ $\left[\mathrm{Ni}\left(\mathrm{pyN}_{2}{ }^{\mathrm{Me}}\right)(\mathrm{OH})\right]^{1-}$ in DMF at room temperature (left). The kinetics trace (black) is overlaid with the one-exponential fit to the data (red) for the same reaction system at $223 \mathrm{~K}$ and $0.5 \mathrm{MPa}$ (right).
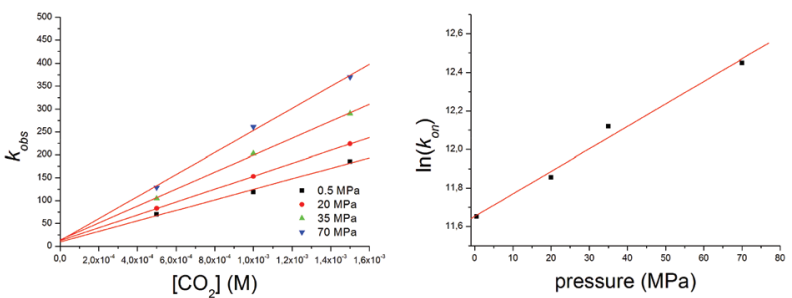

Fig. 3 Plots of the observed rate constants $\left(k_{\text {obs }}\right)$ as a function of $\mathrm{CO}_{2}$ concentration at different pressures: $0.1 \mathrm{mM}\left[\mathrm{Ni}\left(\mathrm{pyN}_{2}{ }^{\mathrm{Me}}\right)(\mathrm{OH})\right]^{1-}$ in DMF at $223 \mathrm{~K}$ (left). Corresponding plot of $\ln \left(k_{\mathrm{on}}\right)$ vs. pressure (right).

In terms of the mechanism of reaction (1), one can envision a transition state that is less or more compact than the product $\eta^{1}-\mathrm{OCO}_{2} \mathrm{H}$ bicarbonate complex. The former will speak in favour of a four-coordinate transition state (hydroxo attack on $\mathrm{CO}_{2}$ followed by a proton transfer) ${ }^{61}$ whereas the latter supports a five-coordinate transition state (insertion of a carbon dioxide $\mathrm{C}-\mathrm{O}$ bond into the $\mathrm{Ni}-\mathrm{OH}$ bond). ${ }^{3}$ This ambiguity is possible to overcome by determining the volume of activation, $\Delta V^{\neq}$, which will offer a clearer picture of the transition state in the solution. Given the information potentially forthcoming from the effects of applied pressure on reaction rates, ${ }^{62-64}$ the high-pressure kinetics of reaction (1) was investigated. To determine the activation volume $\Delta V^{\ddagger}$, pressure-dependent stopped-flow spectrophotometry at low temperature was employed.§ The decrease in absorbance of the $\mathrm{Ni}^{\mathrm{II}}$ complex at $450 \mathrm{~nm}$ and constant temperature, during the course of $\mathrm{CO}_{2}$ binding, was monitored within a pressure range of $0.5-70 \mathrm{MPa}$ (Fig. 2).

Reactions were performed under pseudo-first-order conditions, with $\mathrm{CO}_{2}$ concentrations ranging between 0.5 and $1.5 \mathrm{mM}$ and a $\mathrm{Ni}^{\mathrm{II}}$ concentration of $0.1 \mathrm{mM}$. The temperature of the reaction cell and the solutions was maintained at $223 \pm 0.1 \mathrm{~K}$. Table $\mathrm{S} 1 \dagger$ contains the resulting second order rate constants $\left(k_{\text {on }}\right)$ derived from the slopes of plots of the observed rate constants as a function of $\mathrm{CO}_{2}$ concentration at variable pressures (Fig. 3(left)). At least five kinetic runs were performed per data point up to $70 \mathrm{MPa}$ at $223 \mathrm{~K}$. Under these conditions, the volume of activation is independent of pressure and can be evaluated from the slope of the linear plot $\left(\ln \left(k_{\mathrm{on}}\right)\right.$ vs. pressure $)^{62}$ in Fig. 3 (right). ${ }^{35}$
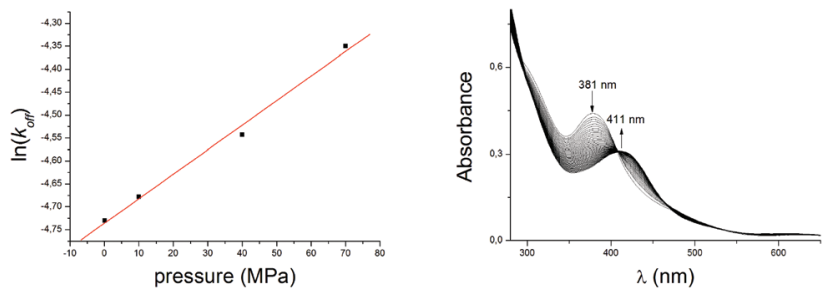

Fig. 4 Plot of $\ln \left(k_{\text {off }}\right)$ vs. pressure for the reaction of $0.08 \mathrm{mM}$ $\left[\mathrm{Ni}\left(\mathrm{pyN}_{2}{ }^{\mathrm{Me} 2}\right)(\mathrm{OH})\right]^{1-}$ with $\mathrm{CO}_{2}$ in DMF at $223 \mathrm{~K}$ (left). Corresponding time resolved UV/visible spectra in the course of the back decarboxylation reaction; $100 \mathrm{~s}$ observation time (right).

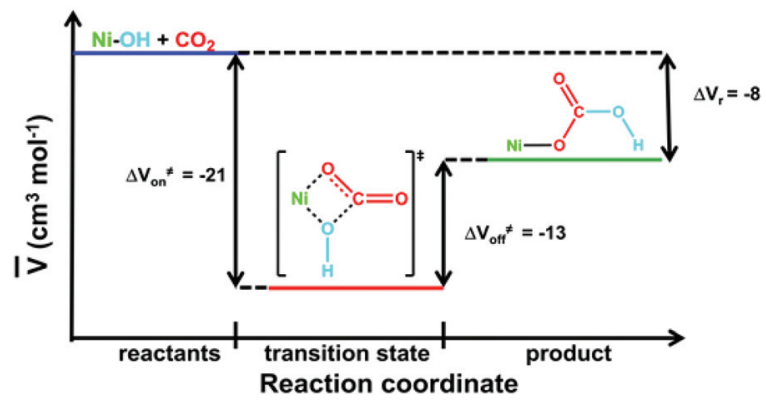

Fig. 5 Volume profile for $\mathrm{CO}_{2}$ fixation in reaction (1).

Analysis of the data leads to $\Delta V_{\mathrm{on}}^{\neq}=-21 \pm 3 \mathrm{~cm}^{3} \mathrm{~mol}^{-1}$ for reaction (1). This value is entirely consistent with the negative value of $\Delta S^{\neq}$for this reaction (Table 1) and supports an associative mechanism where bond breaking does not have a significant role in the rate-determining step. Unlike many classical substitution reactions, there is neither a leaving ligand nor a change in charge. Thus, the observed $\Delta V^{\neq}$corresponds to the intrinsic volume change and directly reflects the transition state at the molecular level. Activation volumes for the same type of reaction are reported only for $\mathrm{CO}_{2}$ uptake by $\left[\mathrm{M}\left(\mathrm{NH}_{3}\right)_{5}(\mathrm{OH})\right]^{2+}$ complexes in aqueous solution $\left(\mathrm{M}=\mathrm{Co}^{\mathrm{III}}\right.$, $\left.-10.1 \pm 0.6 ; \mathrm{Rh}^{\mathrm{III}},-4.7 \pm 0.8 ; \mathrm{Ir}^{\mathrm{III}},-4 \pm 1 \mathrm{~cm}^{3} \mathrm{M}^{-1}\right) .{ }^{61}$ These values are significantly less negative than that of reaction (1), suggesting a more compact transition state in that reaction. By way of comparison, the partial molar volume of $\mathrm{CO}_{2}$ in DMF is ca. $43 \mathrm{~cm}^{3} \mathrm{M}^{-1}$. ${ }^{65}$ By a dilution experiment (stopped-flow mixing of $\left[\mathrm{Ni}\left(\mathrm{pyN}_{2}{ }^{\mathrm{Me} 2}\right)\left(\mathrm{OCO}_{2} \mathrm{H}\right)\right]^{1-}$ with degassed DMF at $223 \mathrm{~K}$ ) at variable pressures we have directly determined the activation volume for the back decarboxylation reaction $\Delta V_{\text {off }}^{\neq}=$ $-13 \pm 1 \mathrm{~cm}^{3} \mathrm{~mol}^{-1}$ (Fig. 4, Table S1†). This enabled us to construct a volume profile (Fig. 5), which clearly indicates that the $\left\{\left[\mathrm{Ni}\left(\mathrm{pyN}_{2}{ }^{\mathrm{Me} 2}\right)(\mathrm{OH})\right]^{1-} \ldots \mathrm{CO}_{2}\right\} \S$ transition state is more compact than the product bicarbonate complex. In addition, based on the kinetic parameters at $223 \mathrm{~K}$ (Table S1 $\dagger$ ) the corresponding binding constant could be obtained as $K_{\mathrm{eq}}^{223}=k_{\mathrm{on}} /$ $k_{\text {off }}=1.3 \pm 0.1 \times 10^{7} \mathrm{M}^{-1}$, which is in accord with the estimations based on the thermodynamic parameters (vide supra).

Such a volume profile supports a five-coordinate transition state with bidentate bicarbonate coordination on the way to the four-coordinate product. 
The four-coordinate structure of the starting complex and the binding of the dinegative pincer ligand enhance the nucleophilicity of a bound hydroxide. This favors an initial nucleophilic attack of a hydroxide and a cycloaddition pathway that should promote fast kinetics. The analogous reactions for the $\left[\mathrm{M}\left(\mathrm{NH}_{3}\right)_{5}(\mathrm{OH})\right]^{2+}$ systems $\left(\mathrm{M}=\mathrm{Co}^{\mathrm{III}}, \mathrm{Rh}^{\mathrm{III}} \text { or } \mathrm{Ir}^{\mathrm{III}}\right)^{61}$ have three orders of magnitude smaller rate constants than that in this study. This parallels a significantly lower nucleophilicity of $\mathrm{OH}^{-}$coordinated to the +3 metal centers within the positively charged $\left[\mathrm{M}\left(\mathrm{NH}_{3}\right)_{5}(\mathrm{OH})\right]^{2+}$ complexes in comparison to the nucleophilicity of $\mathrm{OH}^{-}$within negatively charged [Ni$\left.\left(\mathrm{pyN}_{2}{ }^{\mathrm{Me} 2}\right)(\mathrm{OH})\right]^{1-}$. The steric protection of the activated hydroxide and the increased electron density caused by the pincer ligand control the reaction thermodynamics and leads to a stable $\eta^{1}$-bound product. These collective features render $\mathrm{CO}_{2}$ fixation by $\left[\mathrm{Ni}\left(\mathrm{pyN}_{2}{ }^{\mathrm{Me} 2}\right)(\mathrm{OH})\right]^{1-}$ kinetically and thermodynamically favorable. In addition to reaction $(1),{ }^{3}$ the enthalpic reaction coordinate has also been computed by DFT methods for the slower reaction of $\mathrm{CO}_{2}$ with $\left[\mathrm{Ni}\left(\mathrm{pyN}_{2}{ }^{\mathrm{iPr} 2}\right)(\mathrm{OH})\right]^{1-}\left(k_{\mathrm{on}}=\right.$ $5.1 \times 10^{4} \mathrm{M}^{-1} \mathrm{~s}^{-1}, \Delta S^{\neq}=-27 \mathrm{cal} \mathrm{mol}^{-1} \mathrm{~K}^{-1}$ in DMF) ${ }^{.7}$ Results for both systems indicate a mechanism proceeding by a nucleophilic attack at the carbon atom of $\mathrm{CO}_{2}$ by a hydroxide, formation of a cyclic transition state as depicted in Fig. 5, rupture of one $\mathrm{Ni}-\mathrm{O}$ bond, and reorientation of the resulting monodentate bicarbonate by a Ni-O-C pivot motion. The predicted final perpendicular orientation of the bicarbonate relative to the $\mathrm{NiN}_{3}$ plane is observed in crystalline salt of the reaction products. ${ }^{46}$ The herewith visualized mechanism differs from that reported for $\left[\mathrm{M}\left(\mathrm{NH}_{3}\right)_{5}(\mathrm{OH})\right]^{2+}\left(\mathrm{M}=\mathrm{Co}^{\mathrm{III}}, \mathrm{Rh}^{\mathrm{III}}\right.$ or $\left.\mathrm{Ir}^{\mathrm{III}}\right),{ }^{61}$ where the rate-determining step in decarboxylation proceeds according to a dissociative mechanism that involves breakage of the oxygen-carbon bond on the carbonate ligand. In contrast, our back reaction has a clearly associative character, involving a Ni-O bond formation and closure of a chelate bicarbonate ring. We should point out that the reactions between $\mathrm{CO}_{2}$ and $\left[\mathrm{M}\left(\mathrm{NH}_{3}\right)_{5}(\mathrm{OH})\right]^{2+}$ operate in aqueous solutions, where a hydrogen-bonding network assists in proton transfer from the bound hydroxide to one of the $\mathrm{CO}_{2}$ oxygen atoms. On the other hand, our reaction operates in DMF, within a hydrophobic environment of the sterically bulky ligand, and there is no possibility that the $\mathrm{CO}_{2}$ oxygen atoms can be involved in some prominent hydrogen-bonding interactions. This makes the $\mathrm{CO}_{2}$ oxygen atoms even more nucleophilic and prone to bind to the $\mathrm{Ni}^{\mathrm{II}}$ center, resulting in a fivecoordinate transition state. This may also explain the fact that our interpretation of the overall volume profile is consistent with, and may be said to support, the computed reaction pathway, although these computational models do not address hydrogen bonding. ${ }^{3}$

\section{Conclusions}

Here, we have revealed the thermodynamics of $\mathrm{CO}_{2}$ binding to $\left[\mathrm{Ni}\left(\mathrm{pyN}_{2}{ }^{\mathrm{Me} 2}\right)(\mathrm{OH})\right]^{-}$, which was previously reported as the fastest $\mathrm{CO}_{2}$ fixation reaction by a metal-bound hydroxide. ${ }^{3}$
Based on the determined equilibrium constant of $2.4 \pm 0.2 \times$ $10^{5} \mathrm{M}^{-1}$ at $298 \mathrm{~K}$ and $1.3 \pm 0.1 \times 10^{7} \mathrm{M}^{-1}$ at $223 \mathrm{~K}$, it seems that the thermodynamics of this process is also highly efficient, though there is limited literature information for comparisons. ${ }^{53}$

Our high-pressure kinetic studies revealed a large negative activation volume for both the $\mathrm{CO}_{2}$ uptake and the back decarboxylation reaction. These results support a very compact transition state, which can be visualized as a five-coordinate species with a bicarbonate bound in a bidentate fashion. The observed character of the transition state, in accord with computational results, ${ }^{3}$ explains a very low activation enthalpy and a negative activation entropy consistent with rapid $\mathrm{CO}_{2}$ fixation. Reaction (1) is currently the most thoroughly characterized carbon dioxide fixation reaction by a metal hydroxide complex, and among the more thoroughly examined carbon dioxide fixation reactions of any type.

\section{Acknowledgements}

I.I.-B. and O.T. gratefully acknowledge support from the "Solar Technologies Go Hybrid" initiative of the State of Bavaria. Research at Harvard University was supported by NIH grant GM-28856.

\section{Notes and references}

$\$$ All manipulations and measurements were performed under a pure argon atmosphere. All reagents and solvents were purchased from commercial sources (Sigma-Aldrich, Acros Organics) and were of p.a. grade and used without purification. DMF was purchased as an extra dry solvent and was stored in a sure-seal bottle under argon and molecular sieves. All solutions were prepared in dry DMF in an MBraun inert atmosphere glove box.

$\S$ Measurements were performed using a Hi-Tech Scientific HPSF 56 stoppedflow instrument externally coupled to a Huber CC905 thermostat. UV/visible spectra were recorded using an Energetiq LDLS ENQ EQ-99 FC laser-driven light source coupled to an Applied Photo Physics photomultiplier. Solutions in DMF were prepared immediately before measurement. Lower concentrations of $\mathrm{CO}_{2}$ were obtained by dilution of a saturated solution in graduated gas-tight syringes. Neither the solution of $\left[\mathrm{Ni}\left(\mathrm{pyN}_{2}{ }^{\mathrm{Me} 2}\right)(\mathrm{OH})\right]^{1-}$ nor the $\mathrm{CO}_{2}$ solution was exposed to the atmosphere.

1 R. Angamuthu, P. Byers, M. Lutz, A. L. Spek and E. Bouwman, Science, 2010, 327, 313-315.

2 T. Sakakura, J. C. Choi and H. Yasuda, Chem. Rev., 2007, 107, 2365-2387.

3 D. Huang, O. V. Makhlynets, L. L. Tan, S. C. Lee, E. V. Rybak-Akimova and R. H. Holm, Proc. Natl. Acad. Sci. U. S. A., 2011, 108, 1222-1227.

4 A. M. Appel, J. E. Bercaw, A. B. Bocarsly, H. Dobbek, D. L. Dubois, M. Dupuis, J. G. Ferry, E. Fujita, R. Hille, P. J. Kenis, C. A. Kerfeld, R. H. Morris, C. H. Peden, A. R. Portis, S. W. Ragsdale, T. B. Rauchfuss, J. N. Reek, L. C. Seefeldt, R. K. Thauer and G. L. Waldrop, Chem. Rev., 2013, 113, 6621-6658. 
5 M. Jitaru, J. Univ. Chem. Technol. Metall., 2007, 42, 333334.

6 H. Takeda, K. Koike, H. Inoue and O. Ishitani, J. Am. Chem. Soc., 2008, 130, 2023-2031.

7 T. Inoue, A. Fujishima, S. Konishi and K. Honda, Nature, 1979, 277, 637-638.

8 K. R. Thampi, J. Kiwi and M. Grätzel, Nature, 1987, 327, 506-508.

9 J. Hawecker, J.-M. Lehn and R. Ziessel, J. Chem. Soc., Chem. Commun., 1983, 536.

10 K. Ikeue, H. Yamashita, M. Anpo and T. Takewaki, J. Phys. Chem. B, 2001, 105, 8350-8355.

11 H. Fujiwara, H. Hosokawa, K. Murakoshi, Y. Wada, S. Yanagida, T. Okada and H. Kobayashi, J. Phys. Chem. B, 1997, 101, 8270-8278.

12 J. Grodkowski, T. Dhanasekaran, P. Neta, P. Hambright, B. S. Brunschwig, K. Shinozaki and E. Fujita, J. Phys. Chem. A, 2000, 104, 11332-11339.

13 T. Ogata, S. Yanagida, B. S. Brunschwig and E. Fujita, J. Am. Chem. Soc., 1995, 117, 6708-6716.

14 S. Matsuoka, K. Yamamoto, T. Ogata, M. Kusaba, N. Nakashima, E. Fujita and S. Yanagida, J. Am. Chem. Soc., 1993, 115, 601-609.

15 J. Hawecker, J.-M. Lehn and R. Ziessel, Helv. Chim. Acta, 1986, 69, 1990-2012.

16 H. Hori, F. P. A. Johnson, K. Koike, O. Ishitani and T. Ibusuki, J. Photochem. Photobiol., A., 1996, 96, 171-174.

17 K. Koike, H. Hori, M. Ishizuka, J. R. Westwell, K. Takeuchi, T. Ibusuki, K. Enjouji, H. Konno, K. Sakamoto and O. Ishitani, Organometallics, 1997, 16, 5724-5729.

18 P. Kurz, B. Probst, B. Spingler and R. Alberto, Eur. J. Inorg. Chem., 2006, 2006, 2966-2974.

19 M. Jitaru, D. A. Lowy, M. Toma, B. C. Toma and L. Oniciu, J. Appl. Electrochem., 1997, 27, 875-889.

20 R. Aydin and F. Köleli, J. Electroanal. Chem., 2002, 535, 107-112.

21 A. Begum and P. G. Pickup, Electrochem. Commun., 2007, 9, 2525-2528.

22 C. I. Smith, J. A. Crayston and R. W. Hay, J. Chem. Soc., Dalton Trans., 1993, 3267.

23 C. Dealwis, Electrochim. Acta, 2000, 45, 2061-2074.

24 M. Gattrell, N. Gupta and A. Co, J. Electroanal. Chem., 2006, 594, 1-19.

25 S. Ikeda, T. Takagi and K. Ito, Bull. Chem. Soc. Jpn., 1987, 60, 2517-2522.

26 M. Isaacs, J. C. Canales, A. Riquelme, M. Lucero, M. J. Aguirre and J. Costamagna, J. Coord. Chem., 2003, 56, 1193-1201.

27 S. Kaneco, N.-h. Hiei, Y. Xing, H. Katsumata, H. Ohnishi, T. Suzuki and K. Ohta, Electrochim. Acta, 2002, 48, 51-55.

28 S. Kaneco, K. Iiba, N.-h. Hiei, K. Ohta, T. Mizuno and T. Suzuki, Electrochim. Acta, 1999, 44, 4701-4706.

29 S. Kaneco, R. Iwao, K. Iiba, K. Ohta and T. Mizuno, Energy, 1998, 23, 1107-1112.

30 J. Lee, Y. Kwon, R. L. Machunda and H. J. Lee, Chem.-Asian J., 2009, 4, 1516-1523.
31 J. Lee and Y. Tak, Electrochim. Acta, 2001, 46, 3015-3022.

32 R. Schrebler, P. Cury, F. Herrera, H. Gómez and R. Córdova, J. Electroanal. Chem., 2001, 516, 23-30.

33 R. Schrebler, P. Cury, C. Suárez, E. Muñoz, H. Gómez and R. Córdova, J. Electroanal. Chem., 2002, 533, 167-175.

34 P. J. Welford, B. A. Brookes, J. D. Wadhawan, H. B. McPeak, C. E. W. Hahn and R. G. Compton, J. Phys. Chem. B, 2001, 105, 5253-5261.

35 S. Kern and R. van Eldik, Inorg. Chem, 2012, 51, 73407345.

36 C. Creutz and M. H. Chou, J. Am. Chem. Soc., 2007, 129, 10108-9.

37 J. Dietrich and S. Schindler, Z. Anorg. Allg. Chem., 2008, 634, 2487-2494.

38 Y. Inoue, H. Izumida, Y. Sasaki and H. Hashimoto, Chem. Lett., 1976, 863-864.

39 W. Leitner, Angew. Chem., Int. Ed. Engl., 1995, 107, 23912405.

40 P. G. Jessop, Y. Hsiao, T. Ikariya and R. Noyori, J. Am. Chem. Soc., 1996, 118, 344-355.

41 P. G. Jessop, T. Ikariya and R. Noyori, Nature, 1994, 368, 231-233.

42 Y. Himeda, Eur. J. Inorg. Chem., 2007, 2007, 3927-3941.

43 G. Laurenczy, F. Joó and L. Nádasdi, Inorg. Chem., 2000, 39, 5083-5088.

44 T. Smolinka, M. Heinen, Y. Chen, Z. Jusys, W. Lehnert and R. Behm, Electrochim. Acta, 2005, 50, 5189-5199.

45 E. Simón-Manso and C. P. Kubiak, Organometallics, 2005, 24, 96-102.

46 D. Huang and R. H. Holm, J. Am. Chem. Soc., 2010, 132, 4693-4701.

47 S. W. Ragsdale, Crit. Rev. Biochem. Mol. Biol., 2004, 39, 165195.

48 S. W. Ragsdale and M. Kumar, Chem. Rev., 1996, 96, 25152540.

49 P. A. Lindahl, Biochemistry, 2002, 41, 2097-2105.

50 D. A. Palmer and R. Van Eldik, Chem. Rev., 1983, 83, 651731.

51 A. Looney, R. Han, K. McNeill and G. Parkin, J. Am. Chem. Soc., 1993, 115, 4690-4697.

52 N. Kitajima, S. Hikichi, M. Tanaka and Y. Morooka, J. Am. Chem. Soc., 1993, 115, 5496-5508.

53 W. Sattler and G. Parkin, Polyhedron, 2012, 32, 41-48.

54 C. Bergquist, T. Fillebeen, M. M. Morlok and G. Parkin, J. Am. Chem. Soc., 2003, 125, 6189-6199.

55 X. Zhang and R. van Eldik, Inorg. Chem., 1995, 34, 56065614.

56 X. Zhang, R. van Eldik, T. Koike and E. Kimura, Inorg. Chem., 1993, 32, 5749-5755.

57 D. Huang, O. V. Makhlynets, L. L. Tan, S. C. Lee, E. V. Rybak-Akimova and R. H. Holm, Inorg. Chem., 2011, 50, 10070-10081.

58 A. K. Patra and R. Mukherjee, Inorg. Chem., 1999, 38, 13881393.

59 A. Gennaro, A. A. Isse and E. Vianello, J. Electroanal. Chem. Interfacial Electrochemistry, 1990, 289, 203-215. 
60 M. Tezuka and M. Iwasaki, Chem. Lett., 1993, 427430.

61 U. Spitzer, R. Van Eldik and H. Kelm, Inorg. Chem., 1982, 21, 2821-2823.

62 R. Van Eldik, T. Asano and W. J. Le Noble, Chem. Rev., 1989, 89, 549-688.
63 C. D. Hubbard and R. van Eldik, Inorg. Chim. Acta, 2010, 363, 2357-2374.

64 R. Van Eldik, C. Dücker-Benfer and F. Thaler, Adv. Inorg. Chem., 1999, 49, 1-58.

65 M. Jödecke, Á. Pérez-Salado Kamps and G. Maurer, J. Chem. Eng. Data, 2012, 57, 1249-1266. 